\title{
Toward Anarchy: \\ A Historical Sketch of the Anarchism-Democracy Divide
}

\author{
Markus Lundström ${ }^{1}$
}

This article traces divergent approaches to democracy in the history of anarchist thought. It outlines an anarchist critique of democracy, a defiant composition arrayed against authority, representation and majority rule. Put in contrast to that approach is the anarchist reclamation, the understanding of anarchy as democracy radicalized. The article shows how the critique of democracy typifies classical anarchist thought, while reclamation of democracy breeds in postclassical anarchism after 1939. Yet these lines of thought also coexist historically, and they both continue into our days. Anarchism is now depicted in terms of radical democracy, while a reclaimed critique once again dissociates anarchy from democracy. In an attempt to recognize dialogue between them, this article suggests that divergent approaches articulate an impossible argument that could further the route toward anarchy. [Article copies available for a fee from The Transformative Studies Institute. E-mail address: journal@transformativestudies.org Website: http://www.transformativestudies.org 02020 by The Transformative Studies Institute. All rights reserved.]

KEYWORDS: Anarchism, Democracy, Suffrage, Errico Malatesta, Emma Goldman.

\section{ANARCHISM-DEMOCRACY IN RETROSPECT}

In the crooked history of anarchist ideas and actions, approaches to democracy have indeed been variegated, diverse, and discontinuous. Clearly the anarchist tradition nurtures an emblematic resistance to governance. Democracy, however, could be understood - and have so been, even by anarchists - as a promising effort in an egalitarian, participatory vein. Radical-democratic scholars typically construe democracy as agonistic rather than antagonistic (Mouffe 2013), a lively process rather than a permanent state (Rancière 2006), an

\footnotetext{
${ }^{1}$ Markus Lundström, Ph.D., Stockholm University, Sweden. Address correspondence to: Markus Lundström, e-mail: markus.lundstrom@ekohist.su.se.
} 